\title{
NOTES ON THE TORTRICIDÆ.
}

BY PROF. C. H. FERNALD, STATE COLlEGE, ORONO, MAINE.

At the time when my Catalogue of the Tortricidæ was published, I was inclined to believe that Cacocia transiturana Walk, and C. obsoletana Walk., were the same species, for they were taken in the same localities, and only females of the former and males of the latter species were to be found in collections.

Prof. Forbes has recently sent me two examples for determination, which he bred from two lots of leaf-rollers on the strawberry, in Illinois, and from each lot he obtained males and females, all the males being obsoletana, and all the females transiturana. We may, therefore, consider the question settled by Prof. Forbes, and these two insects are only the two sexes of our species, which should be known as Cackicia obsoletana Walk.

When I was examining these insects, I was struck by the close resemblance which the males bore to Cacocia zapulata Robs. Of this species only two examples, both males, are at present known; one, the type, taken in Illinois, and the other, now in Prof. Riley's collection, taken in Missouri. C. zapulata is considerably larger than obsoletana. It is hoped that Prof. Forbes will be able to settle the question whether these two are distinct from each other or not. He will undoubtedly give us the early stages of obsoletana in his report.

In the Bulletin of the Entomological Commission, No. 6, page 82, Prof. Riley expresses the opinion that Teras oxycoccana Pack., T. cinderella Riley, T. malivorana LeBaron, and $T$. vaccinizvorana Pack., are dimorphic forms of one species. At the time when my Catalogue went to press, I thought it better to allow them to appear as distinct, but made the statement in a foot-note that "surely oxycoccana Pack. must be distinct." I had the type of oxycoccana, and did not feel prepared to admit that an insect so unlike the others could be the same thing.

During last summer Mr. J. B. Smith collected and raised a large number of the so-called cranberry worms in New Jersey, and many were sent to the Department of Agriculture and bred there, so that there seems to be no doubt that Mr. Smith and Prof. Riley have proved the dimorphism of the insect. Mr. Smith had the kindness to send me a considerable number for examination, but they were all the slate-colored form, or $T$. cinderella Riley. I therefore wrote to Prof. Riley, who sent me a gener- 
ous supply of all the forms bred. There were the plain slate-colored form, the slate-colored with red scales mixed in, and the orange-colored form, the malivorana of LeBaron, which, without much doubt, is identical with vacciniivorana, though the type of the latter is lost, and we now have only a brief description to determine it by. Now, what greatly surprised me in the examination was to observe at once that the orange forms were Teras minuta Robs, which was re-described by Zeller as Teras variolana. I have, for several years past, taken a Teras here in considerable numbers, late in September, which I have sent to several correspondents in Europe, who have written me that they were quite unlike anything there. These proved to be like the slate-colored and red mixed form mentioned above, except considerably larger; I can see no difference except in size. There is no cranberry growing where these are found, but other related plants, as blueberry, upon which they might have fed. My impression is that they hibernate in the imago state, but of this I am not sure. A few years ago I received several specimens from Mr. G. M. Dodge, of Glencoe, Neb., "bred on wild rose," which are so like those taken here that I could separate them only by their greater depth of coloring and their much larger size, for they are as much larger than those taken here, as these are larger than those from Prof. Riley, and others from Texas. I received T. minuta from Mr. Dodge, and also from Mr. Morrison, taken in Nevada, and they were also unusually large. I am, therefore, inclined to believe them all the same species, but I am not yet ready to concede that oxycoccana is the same thing. It will be better to allow it to remain separate till it can be proved to be the same, rather than to unite them now, and have to separate them later, should they prove distinct.

The synonomy is as follows:

Teras minuta.

Tortrix minuta, Robs., r869.

Tortrix malivorana, LeBaron, 1870.

Tortrix vacciniivorana, Pack., 1870 .

Teras variolana, Zell, , I875.

The above are the orange forms.

Tortrix cinderella, Riley, 1872.

Riley's name may be used to indicate the slate-colored form.

Robinson's T. minuta was published in February, 1869 , and Packard's

T. oxycoccana not until April, I869.

In December, I878, I visited Prof. P. C. Zeller, and examined the 
types of his N. A. Tortricids. At the time, I did not feel satisfied that Sericoris argyrelana Zell., was distinct from S. coruscana Clem., but allowed both names to remain. After Prof. Zeller's death, his collection passed into the hands of Lord Walsingham, and I wrote to him about the matter. He made an examination and wrote me that they were identical, and that Prof. Zeller had evidently reached that conclusion, for he had placed them together in his collection.

I have recently examined a large number of examples of the European and American Phoxopteris comptana Frol., and compared them critically with Phoxopteris fragarice Walsh \& Riley, and I am convinced that they are the same thing. They are structurally identical, and my European specimens shade off into cinnamon-colored forms, so that I can find no line of distinction between them. The insect must, therefore, be known hereafter as Phoxopteris comptana Frol.

\section{SOME FRAGMENTS OF INSECT STATISTICS.}

BY THOS. E. BEAN, GALENA, ILLS.

* Pupal Term of Arctia nais.

q found June $\mathrm{r} 6, \mathrm{r} 875$, laying eggs in a depression in ground recently dug. Total number of eggs obtained about 500, I 6 th to I $9^{\text {th }}$ of June.

Larvæ began to appear June 24th. They were fed chiefly on Polygonum acre, and one or two species nearest allied to acre, partly on Polygonum aviculare, var. erectum, and partly on red clover.

Pupation began July $23 \mathrm{rd}$, and continued daily to August 8th, inclusive ; a few more pupæ formed to the $\mathrm{r} 6$ th inclusive, when pupation practically ceased. Only 5 pupations occurred later; two about 2 oth of August, one about Ist of October, and two in the last ten days of October.

After losses from larval mortality and escapes, there remained August I6th nearly 200 larvæ, almost mature. These shortly made final moult and early in September almost ceased feeding. The hybernating disposition took possession of them, and out of nearly 200 mature larvae remaining Sept. ist., not more than three formed pupa before winter.

* Gladly giving some attention again to entomology, after several years neglect, I find a few of my former notes, which, as far as they extend, were carefully made, and may be of some use in supplementing other records, or for comparison of localities. 